Ann. Génét. Sél. anim., I975, 7 (4), 445-447.

\title{
DEPRESSED FERTILITY IN ICELANDIC SHEEP CAUSED BY A SINGLE COLOUR GENE
}

\author{
S. ADALSTEINSSON \\ The Agricultural Research Institute, \\ Keldnaholt Vesturlandsveg, Reykjavik, Iceland
}

\section{SUMMARY}

The top dominant allele at the agouti locus $\left(A^{w h}\right)$ in sheep which primarly produces tan colour or white colour in interaction with a piebald gene has been confirmed to depress ewe fertility by o.I 5 lambs per ewe mated possibly in heterozygous as well as in homozygous state.

The top dominant allele at the agouti locus in sheep, $A^{w h}$, which was shown to cause white or tan colour in the Icelandic sheep (ADAlsteinsson, 1970, 1974) was found to have a considerable depressing effect on ewe fertility (Adalsteinsson, 1970).

It has further been demonstrated recently that the $A^{\text {wh }}$ gene produces tan colour in sheep which lack the recessive gene for piebaldness, and pure white colour in sheep which are homozygous for the gene $S^{b}$ of piebaldness (LAUVERGNe, 1975).

The $A^{\text {wh }}$ gene is therefore probably widespread among the sheep breeds of the world, Evidence on that point is available from Australia (Brooker and Dolling, 1969) and from Great Britain (RYDER and LAND, I974).

In light of the above findings it was found to be of interest to examine further the depressing effect of the $A^{\text {wh }}$ gene in the Icelandic Sheep.

In an investigation where completely white ewes were compared to $\tan$ ewes, no difference in fertility was found between completely white ewes one hand and tan ewes on the other hand (Adalsteinsson, 1975).

Additional data on the performance of nonwhite ewes were also available from the same source as the data on the white and tan ewes. These nonwhite ewes were of several colours, but mainly grey, black badgerface, black mouflon, black or brown.

In table $\mathrm{I}$ is shown a comparison of the fertility of these nonwhite ewes, which lack the $A^{\text {wh }}$ gene,

Annales de Génétique animale. - 1975. 
with the fertility of the white and tan ewes mentioned above, which carry the $A^{\text {wh }}$ gene. The basis of the comparison is the same as described elsewhere when white and tan ewes were compared (Adalsteinsson, 1975).

Table I also shows in summarized form the results from the earlier investigations on the effect of the $A^{w h}$ gene on ewe fertility (Adalsteinsson, 1970).

The depressing effect of the $A^{w h}$ gene on ewe fertility is seen to occur at all ewe ages in the new data set, and the average depressing effect in the present study is the same as that of the previous study, or o.I5 lambs per ewe mated and alive at lambing time.

The effect of the $A^{w h}$ gene was ascribed to increased loss of white or $\tan \left(A^{w h}\right)$ foetuses in white or $\tan \left(A^{w h}\right)$ ewes. Heterozygosity for the $A^{w h}$ gene was not found to diminish this effect (Adalsteinsson, 1970).

\section{TABLE I}

Difference between nonwhite ewes (A) and white or tan ewes (B) in numbers of lambs per ewe

Différence entre les brebis non blanches (A) et les brebis blanches ou rouges et blanches (B) pour le nombre d'agneaux par femelle

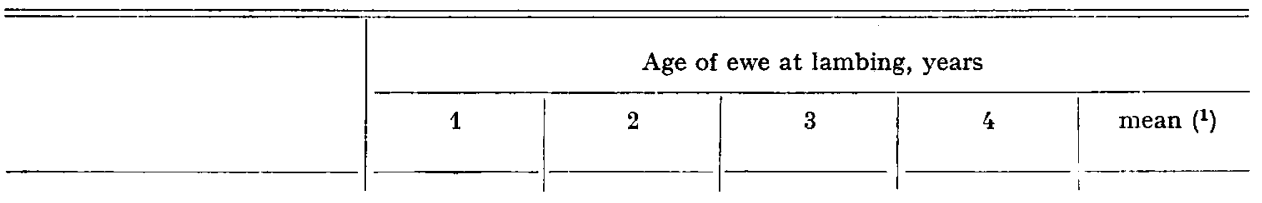

\section{Presents results}

Number of ewes :

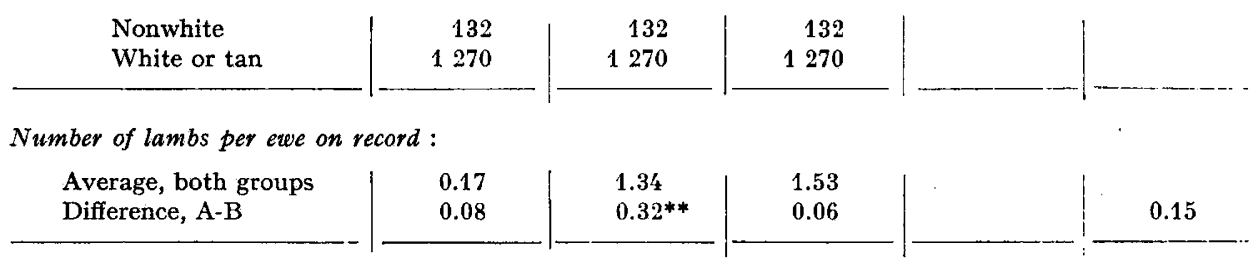

Previous results (Adar.steinsson, 1970):

Numbers of ewes:

Nonwhite

White
465

2035
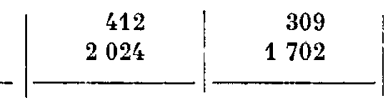

Number of lambs born per mating :

Average, both groups

Difference, A-B

$\mid$

1.23

$0.12 * *$
1.28

$0.18^{* *}$
1.37

$0.14 * *$

(1) Unweighted mean.

** $\mathrm{P}<0.01$.

The two investigations described here, which are carried out on independent data give very similar results. The depressing effect of the $A^{w h}$ gene on ewe fertility seems therefore to be well established within the Icelandic sheep breed. 


\section{RÉSUMÉ}

\section{UN SIMPLE GÈNE DE COLORATION QUI ABAISSE}

\section{LA FERTILITÉ DU MOUTON ISLANDAIS}

L'allèle dominant en tête de la série au locus Agouti chez le mouton $\left(A^{w h}\right)$ colore la toison en rouge ou, parfois, en blanc, par interaction avec un gène de panachure. La présente étude confirme que ce gène $A^{\text {wh }}$ est responsable d'un abaissement de la fertilité des femelles : o, I 5 agneau en moins par brebis mise à la lutte. L'effet semble le même chez l'hétérozygote que chez l'homozygote.

\section{REFERENCES}

Adalsteinssox S., I970, Colour inheritance in Icelandic sheep and relation between colour, fertility and fertilization. J. Agr. Res. Icel., $2: 3-135$.

Adalsteinsson S., I975. Effect of genes for tan colour on productivity in Icelandic sheep. Ann. Génét. Sél, anim, 7, 357-364.

Lauvergne J. J., 1975. Génétique de la couleur de la toison de trois races ovines françaises : Solognote, Bizet et Berrichonne. Ann. Génét. Sêl. anim. 7, 263-276.

RYDek M. L., LAND R. B., I974. Coat colour inheritance in Soay, Orkney, and Shetland sheep. J. Zool., Lond., $173: 477-485$. 